\title{
Flexible contracts and human capital investments
}

Citation for published version (APA):

Fouarge, D., de Grip, A., Smits, W., \& de Vries, M. R. (2011). Flexible contracts and human capital investments. METEOR, Maastricht University School of Business and Economics. METEOR Research Memorandum No. 051 https://doi.org/10.26481/umamet.2011051

Document status and date:

Published: 01/01/2011

DOI:

10.26481/umamet.2011051

Document Version:

Publisher's PDF, also known as Version of record

\section{Please check the document version of this publication:}

- A submitted manuscript is the version of the article upon submission and before peer-review. There can be important differences between the submitted version and the official published version of record.

People interested in the research are advised to contact the author for the final version of the publication, or visit the DOI to the publisher's website.

- The final author version and the galley proof are versions of the publication after peer review.

- The final published version features the final layout of the paper including the volume, issue and page numbers.

Link to publication

\footnotetext{
General rights rights.

- You may freely distribute the URL identifying the publication in the public portal. please follow below link for the End User Agreement:

www.umlib.nl/taverne-license

Take down policy

If you believe that this document breaches copyright please contact us at:

repository@maastrichtuniversity.nl

providing details and we will investigate your claim.
}

Copyright and moral rights for the publications made accessible in the public portal are retained by the authors and/or other copyright owners and it is a condition of accessing publications that users recognise and abide by the legal requirements associated with these

- Users may download and print one copy of any publication from the public portal for the purpose of private study or research.

- You may not further distribute the material or use it for any profit-making activity or commercial gain

If the publication is distributed under the terms of Article $25 \mathrm{fa}$ of the Dutch Copyright Act, indicated by the "Taverne" license above, 


\section{Maastricht University}

Didier Fouarge, Andries de Grip, Wendy Smits, Robert de Vries

Flexible contracts and human capital investments

$\mathrm{RM} / 11 / 051$

\section{METEOR}

Maastricht University School of Business and Economics

Maastricht Research School of Economics

of Technology and Organization

\section{P.O. Box 616}

NL - 6200 MD Maastricht

The Netherlands 


\title{
Flexible contracts and human capital investments
}

Didier Fouarge*, Andries de Grip*, Wendy Smits**, Robert de Vries**

* Research Centre for Education and Labour Market (ROA), Maastricht University

** Statistics Netherlands

\section{Corresponding author:}

Didier Fouarge

ROA, Maastricht University

P.O. Box 616

NL - 6200 MD Maastricht

d.fouarge@maastrichtuniversity.nl

\begin{abstract}
As suggested by human capital theory, workers with flexible contracts participate less often in training than those with permanent contracts. We find that this is merely due to the fact that flexworkers receive less employer-funded training, a gap they can only partly compensate for by their own training investments. Flexworkers particularly participate less in firm-specific training that is meant to keep up with new skill demands than workers with permanent contracts. However, for those who participate in employer-funded firm-specific training, a temporary contract appears to facilitate the transition to a permanent contract with the same employer. However, this does not hold for participation in self-paid training. This training, which is usually general training, does not help in finding a better job.
\end{abstract}

JEL-codes: J24, J41, J62

Keywords: flexible contracts, employer-funded training, self-funded training, labour market mobility 


\section{Introduction}

In 2010, about one out of ten Dutch worker had a flexible contract. Flexible labour contracts enable firms to adjust employment to a fast-changing environment, as in a sudden collapse in product demand. The recent economic crisis clearly showed how firms that were heavily affected by the unexpected fall in product and service demand directly disposed of their workforce with temporary contracts and those employed via temporary work agencies (Glassner and Galgóczi 2009). At the same time, the continuous shifts in skills demanded in the labour market also require that workers participate in training courses that update their skills (Allen and De Grip 2012). When workers with temporary contracts play a major role in the adjustment process in the labour market, particularly these workers should be able to adjust their skills to the shifts in the skill demands.

This paper investigates the extent to which the participation in training among flexworkers is similar to that of workers with permanent contracts, and to what extent differences in training participation are associated with differences in mobility in the internal or external labour market. While most studies in the field compare temporary workers to permanent workers (Booth et al. 2002), we are able to distinguish between four different kinds of contract arrangements: permanent contracts, temporary contracts, temporary work agency contracts, and on-call contracts. Moreover, we are able to distinguish between employer-funded training and self-funded training, whereas most studies only focus on employer-funded training (Albert et al. 2005). This enables us to analyze whether flexworkers could compensate a lack of employer-funded training by their own investments in training. Finally, we are able to distinguish between general training which increases a worker's opportunities for another job, and firm-specific training which focuses on the skills needs in the current job.

Human capital theory predicts that firms will not invest in training for employees who are likely to leave the firm soon, because the period in which they can reap the benefits of such investments is short (Bassanini et al. 2007). ${ }^{1}$ When this is the case, the future employability of flexworkers would be at risk when they face skills obsolescence at some stage in their working life. This risk is particularly large when there is a low transition probability of employees with flexible labour contracts to permanent employment. This would mean that flexworkers are 'trapped' in this type of contract due to low levels of human capital investment (Dekker 2007). However, this will not be a problem if flexible workers compensate for the lack of employer-funded training through their own human capital investments, or when flexible workers can make a transition to permanent employment in which workers can catch up in the development of their skills.

\footnotetext{
${ }^{1}$ Economic literature suggests the existence of a possible trade-off between temporary contracts and investments in human capital (Arulampalam and Booth 1998).
} 
There are few institutional restrictions on the use of fixed-term contracts in the Netherlands, and employment protection for temporary employment is far less strict than for permanent employment (OECD 2004). Until 1999, when the Flexibility and Security Act was put into place, employers could renew temporary contracts only once. Since that date, employers can renew temporary contracts up to three times, although for a limited contract period. There are also few institutional arrangements for the training of flexworkers. Human capital investments for temporary work agency workers are facilitated through the Sector Fund for Education and Development of Temporary Work Agencies (STOOF). STOOF was set up in 2003 to advise, stimulate, and co-finance training activities in temporary work agencies. The training fund available through STOOF is created by a levy of employees’ wages.

Our analyses are based on large representative data for the Dutch workforce: the panel data of the Labour Force Survey. A distinguishing feature is that we use the longitudinal feature of this data to study employment mobility patterns of workers with different kind of contracts. The data does not allow us to instrument the training participation decision. ${ }^{2}$ Our analyses therefore document, albeit in a detailed way, the correlations between various types of contract (permanent contracts, temporary contracts, temporary work agency contracts, and on-call contracts), various types of training investments (no training, employer-funded or self-funded training), and various mobility patterns (remaining on a flex contract with the same employer, transition to a permanent contract with the same employer, a flex contract with another employer, a transition to a permanent contract with another employer, and losing employment).

We show that workers with flexible contracts participate less often in employer-funded training than those with permanent contracts, and that flexworkers can only partly compensate for this gap by their own training investments. Especially those who work on temporary contracts lag behind in terms of employerfunded training. Flexworkers invest most in their own training but these investments do not fully bridge the training-participation gap. The lower training participation of flexworkers suggests that their adaptability to changing skill demands in the labour market is likely to lag behind compared to that of workers with a permanent job. Therefore, workers with flexible contracts may be stuck in these flexible jobs all through their working lifes and will experience difficulties remaining employed when skill demands in the labour market change. However, this does not hold for workers with flexible contracts whose participation in employer-funded firm-specific training helps in making a transition towards a permanent contract with a firm whose training participation is part of the selection process in the temporary jobs they offer new employees (Autor 2001). However, those who do not participate in employer-funded firm-specific training cannot adequately compensate for this difference by investing in

\footnotetext{
${ }^{2}$ In particular, the data do not allow for the estimation of fixed-effects models. Moreover, the data do not include exogeneous variables that could be used to instrument the training participation decision.
} 
self-funded training (mostly with a general character), since we show that the latter does not help in finding a better job.

The paper is organized as follows. Section 2 gives a brief overview of the Dutch institutional context and the theoretical background on the relation between flexible labour contracts and human capital investments. The data used is presented in Section 3. Section 4 analyses the relation between different kinds of labour contracts and workers' training participation. The analyses focus on the probability to engage in employer-funded or self-funded training, as well as on the question whether the training is general or firm-specific. In Section 5, we analyse the relation between the training participation of flexworkers and their future labour market position. Section 6 summarizes our main findings and concludes.

\section{Theoretical background and prior research}

\subsection{Theoretical background}

Within labour economics, investments in workers' skills are the backbone of human capital theory. The central principle of human capital theory is that the knowledge and skills acquired in training represent human capital, which is valued by employers because it leads to higher productivity (Becker 1975). Employers will invest in the training of their workers if the expected rate of return from the investment in training is higher than the rate of return on alternative investments with a similar risk (as represented by the market interest rate). Of course, the expected rate of return on training for the firm is dependent on training costs and benefits. The firm will be able to appropriate some of the benefits of training as long as the higher productivity of its workers is not completely offset by higher wages. According to human capital theory, employees' motivations to invest in their own human capital do not differ fundamentally from employers' motivations. Employees benefit from training if it leads to higher wages. How the training benefits are shared between the firm and the employees depends on both the firm specificity of the training and the investment horizon, that is, the time window in which the benefits of training can be reaped.

Human capital literature in particular focuses on the differences between general and firm-specific training to emphasize the differences between training that raises the productivity of workers in all firms, and training that only increases workers' productivity in the firm that is providing the training. Since firm-specific training is of no or only limited value to other firms, it will not increase employees' market wages, allowing firms to pay their employees less than the value of their productivity. General training, however, is also valuable for other firms and will thus lead to an increase in employees' market wages, limiting the firm's possibilities of appropriating the benefits from training. 
Becker's (1975) argument that firms only benefit from firm-specific training was later modified by various studies, such as Katz and Ziderman (1990), Stevens (1994), Booth and Chatterji (1995), Booth and Snower (1996), Acemoglu and Pischke (1998), and Lazear (2009). These studies focus on three related arguments. Firstly, several studies argue that training enables firms to acquire private information on employees' skills and abilities (e.g., Katz and Ziderman 1990, Acemoglu and Pischke 1998). Secondly, some studies focus on labour market imperfections that give firms some market power in setting wages. Stevens (1994) argues that when training is transferable between firms with market power in setting wages, the potential benefits from training are not only for the firm providing the training and the employee who has been trained, but also for other firms that can poach the trained employees. In addition, since the poachers acquire some of the benefits from training, there is no way for the employee demanding the training or the firm supplying it to capture all the rewards from this training. Inevitably, this leads to an underinvestment in training, particularly for employees with flexible contracts, since these contracts reflect a lack of mutual commitment between the firm and employee. Thirdly, and more recently, Lazear (2009) showed that training cannot simply be decomposed into general and specific components, since all firms require a firm-specific mix of different kinds of general skills. This skillweights approach claims that therefore all training is part of employees' firm-specific human capital.

Actually, for both employees and employers, the investment horizon is particularly important in determining the amount of training investments, as well as the sharing of the costs. For a given level of training costs and training benefits per period, the shorter the expected investment horizon, the lower the rate of return on the investment will be. For firms, the investment horizon equals the expected time employees will remain within the organization. For employees, the investment horizon is closely related to the specificity of the training. If the training is firm specific, the investment horizon is the length of time employees expect to stay with the firm. If the training is general, the investment horizon is the time they expect to remain on the labour market. Employers will therefore be less likely to train employees with temporary contracts, since they do not intend to continue relations with these employees for long. Moreover, they will perceive a higher risk that these employees will leave the firm relatively soon. For employees, the willingness to invest in training depends only on the type of contract if the training is firm specific. Crawford $(1988,1990)$ analysed training investments in the more general context of relationspecific capital productivity, that is, human capital whose productivity depends on the continuation of the relation. Crawford argued that if there is no long-term contract to commit to future compensation for sunk costs of training investments, the firm and the worker will agree to underinvest. Temporary contracts will therefore lead to a lower participation in training than permanent contracts.

\subsection{Prior research}

Several studies show that training participation of workers with temporary contracts is significantly lower than that of workers with permanent contracts (e.g., Booth et al. 2002, Forrier and Sels 2003, Almeida- 
Santos and Mumford 2004, Albert et al. 2005). Booth et al. (2002) found that, in the UK, work-related training is $12 \%$ lower for male employees on fixed-term contracts and $20 \%$ lower for those on seasonalcasual contracts compared to male employees with a permanent contract. Female employees on fixedterm contracts have a 7\% lower probability of being trained than permanent employees, while those with a seasonal-casual contract have a 15\% lower probability to participate in a training course. Using matched employer-employee data for the UK, Murphy et al. (2008) showed that employees on temporary contracts are 6-9\% less likely to participate in training compared to employees on permanent contracts. In their study on the Australian labour market, Draca and Green (2004) also found that employees in flexible employment face a substantially lower probability of receiving employer-funded training. The authors found that these differences are even more marked for training intensity, as indicated by the duration of the training and the number of courses in which workers participate. For the Netherlands, Jonker and De Grip (1999) also found that employees with temporary contracts receive half as much training as employees with permanent contracts, although they do not find that the duration of the training is shorter. More recently, De Graaf-Zijl et al. (2010) reported a significant 12\% difference in the participation of employer-paid training between employees with a temporary contract and those with a regular job.

Concerning the labour mobility prospects of flexworkers, Booth et al. (2002) examined whether temporary jobs in the UK are 'dead end' jobs with poor pay and prospects or 'stepping stones' to permanent employment. The authors found that fixed-term contracts are effective stepping stones to permanent work, but this does not hold for casual-seasonal employment. Dekker (2007) found comparative evidence for the UK, Germany, and the Netherlands and concluded that, although mobility to permanent employment is low, flexible employment acts as a stepping stone to standard employment.

Another strand of literature considers the transition probabilities from unemployment to employment for persons who had a temporary job before they became unemployed. Arranz et al. (2010), for example, showed that temporary workers who became unemployed at the end of their temporary contract are more likely to exit unemployment through another temporary contract than through permanent employment. In the same vein De Graaf-Zijl et al. (2010) found that although previous employment in a temporary job shortens unemployment spells, temporary workers do not have better prospects for finding a permanent job in the years after their unemployment. However, these studies do not consider whether this mobility pattern is related to training participation.

Loewenstein and Spletzer (1997) found that training often takes place after a few years of job tenure. They argue that employers may be reluctant to invest in the training of employees until they have more evidence on the quality of the worker-firm match. This suggests that firms will also not invest in the training of employees who are in a temporary job, which is meant to be a selection period for permanent employment at the firm. However, Autor (2001) found that temporary work agencies do invest in the 
training of their employees. Building on the studies of Katz and Ziderman (1990) and Acemoglu and Pischke (1998), Autor argued that temporary work agencies provide up-front training during unpaid hours prior to offering a permanent contract. This is because, in addition to developing human capital, this training serves two complementary functions. First, the opportunity to be trained induces self-selection, enabling the agency to recruit employees with valuable unobserved ability (see also Barron et al. 1989). Second, it facilitates employee screening by generating private information on the skills and abilities of employees. The key premise of Autor's model is that training is more productive for high-ability employees. The implication of this positive selection is that temporary work agencies not only provide flexible spot market labour to other firms, but also information on employee quality.

\section{Data and empirical approach}

We make use of the Dutch Labour Force Survey (LFS) for the years 2004-2008. This survey is a rotating panel survey among 65,000 households a year. Within each household, all persons aged 15 or older are interviewed, but we focus our analyses on working individuals of the age 15-64. Households are followed during one year on a quarterly basis. After the first face-to-face interview, households are contacted four more times by telephone. The period between two interviews is about three months. Because of the panel character of the survey, the LFS is very suitable for the analysis of labour market dynamics (Bierings et al. 2009, Kerkhofs et al. 2009). The LFS contains detailed information on the type of contract, training participation, and the occupational background of employees, as well as firm characteristics.

We distinguish between four different types of contract arrangements: permanent employment, temporary work agency employment, on-call employment, and temporary contracts. Permanent employment refers to contracts with a fixed number of hours and a contract duration that is not determined. Other types of employment are defined as flexible contracts, and information on the terms of employment is used to define the type of flexible contract: temporary work agency contracts, on-call contracts (contracts without a fixed number of working hours), and temporary contracts (contracts with a duration of less than two years). ${ }^{3}$ In this study we exclude students, the self-employed and workers who are working for fewer than 12 hours a week. ${ }^{4}$

The information on training pertains to the training the respondent followed at the time of the first interview or, up to four weeks before the first interview. ${ }^{5}$ As a consequence, training participation in short

\footnotetext{
${ }^{3}$ Workers on a temporary contract that, after a probationary period, will be converted to a permanent contract are classified as permanent workers.

${ }^{4}$ This means that individuals with on-call contracts who are not currently working or working for fewer than 12 hours a week have been left out of the analyses.

${ }^{5}$ In case a respondent participated in more than one training event, he is asked to report on the most important one from the perspective of his current occupation.
} 
training courses is probably underestimated. The LFS also contains information on who paid for the costs of training. We define employer-funded training as training for which the employer paid the costs of training either in full or in part. Self-funded training pertains to training that was fully paid for by the employee herself. ${ }^{6}$ Our data allow us to look into the reason why workers participate in training: (1) to keep up with new skills demands, (2) because it is compulsory, (3) in order to make a promotion, (4) to improves the chances for another job, and (5) non-work related reasons. Although the distinction between general and firm-specific training is a rather crude one (Lazear 2009), we assume that the first three motives pertain to firm-specific training, while the last two motives refer to general training.

We perform multivariate analyses for the probability of participating in training, and the type of training (employer-funded versus self-funded, and general versus firm-specific training). These analyses focus on the relation between the contract type and the training probability, and control for a large set of individual, job and firm characteristics as well as external conditions: gender, age and age squared, ethnicity, educational level, occupation, part-time work, job tenure (in log), industry sector, as well as region and time dummies. Summary statistics of all these variables are reported in the Appendix (Table A.1). From human-capital theory, we expect that flexworkers participate significantly less often in training than workers with permanent contracts. In particular, we expect that this is particularly due to a lower participation in employer-funded training as employers who fund most training costs have less incentives to invest in the human capital of their flexible workforce than in the workers with permanent contracts.

Mobility is measured by comparing the employment situation at the time of the fifth interview with that at the first interview one year earlier. Respondents are asked whether they are still with the same employer and whether they still have the same type of work arrangement. This allows us to distinguish among five possible labour mobility patterns for flexible workers: (1) remaining on a flex contract with the same employer, (2) transition to a permanent contract with the same employer, (3) transition to a flex contract with another employer, (4) transition to a permanent contract with another employer, and (5) losing employment (i.e. making a transition to unemployment or inactivity).

We analyse the relation between labour market mobility, type of contract and training participation by estimating a multinomial logit model for the probability of experiencing the various types of mobility. This analysis controls for the same set of variables as those included in the training participation models. From human-capital theory, we expect flexworkers who received employer-funded training, especially when this training is firm-specific, to remain with their employer because the employer is willing to reap

\footnotetext{
${ }^{6}$ No more than $2 \%$ of all training is neither financed by the employer nor the employee. These cases are included in our analyses for total training participation. When we distinguish between employer-funded and self-funded training (e.g. Table 3 and following), these cases are excluded.
} 
the benefits from its investment (Autor 2001). Previous empirical studies, however, have shown that the relation between training participation and mobility on the external job market is ambiguous. Lynch (1993) and Parent (1999), for example, showed that workers who participate in employer-funded training are indeed less likely to switch employer, but Goux and Maurin (2000) and Bassanini et al. (2005) found that there is no significant difference in external labour mobility between workers who did and those who did not participate in any employer-funded training. Furthermore, we expect self-funded training to be related to transitions to a permanent contract with another employer since flexworkers will particularly pay for their own training when they expect favourable external labour market opportunities.

\section{Training participation of flexworkers}

Table 1 shows the training participation by contract type. As expected, employees with permanent contracts participate more often in training than workers with flexible work arrangements. This confirms earlier findings by Booth et al. (2002) for the UK. In 2004-2008, the training participation rate of workers with a permanent contract was $11.5 \%$, whereas only $9.5 \%$ of workers with a flexible work contract participated in training. There are considerable differences, however, between different types of flexible work arrangements. Training participation is particularly low among workers on on-call contracts.

The greater part of the training is funded by the employer (see also Pischke 2001). However, as can be expected from human capital theory, workers with flexible contracts participate less often in employerfunded training. The latter is in line with earlier findings by Albert et al. (2005) who show that workers with temporary contracts are less often employed in firms which offer training, and even when they are employed in such firms they have a lower probability to participate in training. However, flexible workers more often participate in training courses they pay themselves than workers with permanent contracts. Whereas only one out of eight workers with a permanent contract who participate in training pay their training costs themselves, more than a third of the flexworkers bear the full costs of their training. This is likely due to the shorter expected time horizon in which employers have to recoup their training investments in flexible workers. The latter particularly holds for those who work on a temporary contract. However, Table 1 clearly shows that flexworkers do not manage to fully compensate for the lower training provision from their employer by their own training investments. This is an interesting finding considering that earlier research (e.g. Booth et al. 2002, De Graaf-Zijl et al. 2010) has merely focused on employer-funded training. Obviously, the inadequate compensation for the lack of employer-funded training may be due to the uncertainty flexworkers face with respect to the returns on human capital investments, as they are uncertain whether they could find a job in which a particular human capital investment is productive when their current labour contract terminates.

\section{$<$ INSERT TABLE 1 ABOUT HERE $>$}


As Table 2 shows, the most important reason to participate in training is to keep up with new skill demands. However, this reason holds far less for workers who have a temporary contract and for those who are employed by a temporary work agency. Employees with temporary contracts and those who work for temporary work agencies participate more often in training with the aim of increasing their opportunities to obtain a different job. This suggests that they particularly participate in training - often at their own costs (as Table 3 shows) - with the aim to improve their labour market prospects.

\section{$<$ INSERT TABLE 2 ABOUT HERE $>$}

Table 3 shows that employer-funded training is most often firm-specific. For permanent workers, only less than one out of five training has a general character. ${ }^{7}$ However, this share is larger for flexible workers: one out of four employer-funded training courses has a general character. This share is even larger for workers who have a temporary work agency contract or a temporary contract. Self-funded training is by and large general. As can be expected from the human capital model, the participation in self-funded training is higher among flexworkers than among workers with a permanent contract.

In the logit analysis reported in the Appendix (Table A.2), we show that conditional on the fact that workers receive employer-funded training, those who are employed on a temporary work agency contract or a temporary contract are significantly more likely to receive general rather than firm-specific training compared to workers with a permanent contract. The fact that employers do pay for general training could be due to the fact that the particular mix of different kinds of general training is firm specific (Lazear, 2009), or that firms want to commit their employees to the firm (Lee and Bruvold 2003). Especially in the case of flexible workers, firms might pay the costs of general training because they want to learn about workers’ abilities (Acemoglu and Pischke 1998).

\section{$<$ INSERT TABLE 3 ABOUT HERE $>$}

Table 4 shows the estimation results of a logit analysis for the probability of participating in training for flexworkers compared to those who have a permanent contract. Table 4 also reports the results from a multinomial logit model where we distinguish between employer-funded training and self-funded training. The table shows that, as expected, training participation is significantly lower for workers with a flexible work arrangement. The difference in training participation is especially large for workers on a temporary-help agency or temporary contract: compared to permanent workers, their probability of training is about $3 \%$ lower. However, the estimation results from the multinomial logit model in columns 2 and 3 show that this only holds for employer-funded training. De Graaf-Zijl et al. (2010) also find that

\footnotetext{
${ }^{7}$ This is calculated as $1.7 \%$ / $(7.1 \%+1.7 \%)$.
} 
flexible workers receive less employer-funded training. Conversely, except for on-call workers, workers with flexible contracts have a higher probability of participating in self-funded training. These estimation results show that workers with a flexible contract partly compensate for the lack of employer-funded training by their own training investments. This also explains why their training usually does not focus on the skills they need for their current job but, instead, on the skills they need for applying to another job, as shown in Table 2.

\section{$<$ INSERT TABLE 4 ABOUT HERE>}

\section{Training participation and labour mobility}

Table 5 presents descriptive evidence on the relation between workers' employment contract, training participation and various types of labour mobility within a year: losing employment (compared to remaining employed), making a transition to a permanent job (compared to making a transition to flexible employment), and making a transition to another employer (compared to remaining with the same employer). ${ }^{8}$ The table shows that the correlation between training participation and the loss of employment is negative: workers who participated in training are less likely to lose employment than those who did not participate in any training course. This is in line with earlier studies for the Netherlands which showed that workers who participated in training have a lower probability to become unemployed (Fouarge et al. 2009). The relative difference in the risk of losing employment between workers who participated in training and those who did not is larger for workers with permanent employment than for workers with flexible employment. ${ }^{9}$ Moreover, the absolute risk of losing employment is larger for flexworkers. However, there are considerable differences between workers with different types of flexible contracts. For workers with an on-call contract and for those employed by a temporary work agency, the negative relation between training participation and the probability to become unemployed is substantial. Conversely, for workers on a temporary contract there is virtually no difference in the probability of losing employment between those who participated in training and those who did not.

Table 5 also shows that for workers with temporary contracts as well as those employed by temporary work agencies, training participation is related to the probability of obtaining permanent employment. For both types of flexible workers, the differences in the probability to get a permanent contract between trained and untrained workers are large and significant. However, for workers with an on-call contract, training participation is hardly related to the probability to get a permanent contract.

\footnotetext{
${ }^{8}$ Note that these transitions are not mutually exclusive (e.g. a transition to another employer could coincide with a transition to a permanent job). Mutually exclusive labor market transitions of flexible workers are shown in Table 6. ${ }^{9}$ This is due to differences in the composition (such as age) of the groups.
} 
There are also substantial differences in job mobility between different types of flexworkers. Those with a temporary contract and those who are employed by a temporary work agency change employers more often than workers on an on-call contract. However, although flexworkers who participate in training in general more often stay with their employer than those who do not train, there are differences according to the type of contract. For both workers with a temporary contract and those working for a temporary work agency training participation is positively related to the likelihood that they stay with their employer. However, workers with on-call contracts who participate in training are more likely to leave their employer than those who did not participate in any training course.

\section{$<$ INSERT TABLE 5 ABOUT HERE $>$}

Table 6 shows the estimation results of a multinomial logit analysis for the full set of possible labour market transitions for workers with flexible contracts. ${ }^{10}$ In this analysis, we distinguish between (1) the probability of remaining employed on a flex contract with the same employer, (2) the probability of getting a permanent contract with the same employer, (3) the probability of getting a flex contract in another firm, (4) the probability of getting a permanent contract in another firm, and (5) the probability of losing employment (i.e. making a transition to unemployment or inactivity). In all analyses, remaining employed on a flex contract with the same employer is the reference group.

Table 6 shows that flexworkers who have an on-call contract more often get a permanent contract with their employer than temporary work agency workers (the reference group). However, those with an oncall contract are less likely to switch to a flexible or permanent job in another firm. Moreover, they are less likely to lose employment. Temporary contracts are associated to a lower likelihood of changing employer (irrespective of the contract type), but employees with such contracts face a higher probability of losing employment.

\section{$<$ INSERT TABLE 6 ABOUT HERE $>$}

The estimation results confirm that the relation between the training participation of flexworkers and their labour market mobility depends on who paid for the training. As expected, flexworkers' participation in employer-funded firm-specific training is positively related to the transition to a permanent contract with the current employer, and negatively related to the probability to get a flexible contract with another employer and the probability of losing employment. These findings are in line with prior studies by Lynch (1993) and Parent (1999), and suggest that firms invest in the firm-specific skills of flexible workers if they aim to continue the employment relationship for a longer period. This is consistent with the idea that

\footnotetext{
${ }^{10}$ The analysis excludes workers with a permanent contract.
} 
firms use this type of training in the selection process for their flexible workers (Autor 2001). However, there is no relation between flexworkers' participation in employer-funded general training or self-funded training and the probability to get a permanent contract with the current employer. Moreover, and contrary to our expectations, we do not find a significant correlation between self-funded training of flexworkers and the probability to get a permanent contract in another firm. ${ }^{11}$ This suggests that, for flexworkers, selffunded training does not contribute to improving their opportunities for obtaining a permanent job. ${ }^{12}$ Moreover, the estimation results show a positive correlation between paying for one's own training and the probability of losing employment. This, however, might be due to a selection effect as particularly those who run the risk of losing their jobs may try to improve their labour market position by investing in further training.

Our analyses suggest that employer-funded firm-specific training contributes to improve the labour market position of flexworkers. However, employer-funded general training and self-funded training do not help to improve the labour market position of flexworkers. This could be because general training is more often not work related ${ }^{13}$ or because such training is directed to improve the prospects of flexworkers with the precarious labour market opportunities. In both cases - which are hard to test empirically human capital theory predicts zero or very low returns.

\section{Conclusion $^{14}$}

Although the differences in training participation have decreased in recent years, the estimation results presented in this article confirm the hypothesis from human capital theory that workers with a flexible labour contract participate less often in training than those with a permanent contract. This holds for all types of flexworkers, although there are considerable differences between the various types of flexible work arrangements. The lower training participation of flexworkers is merely due to the fact that these workers get less employer-funded training. Workers with a flexible contract partly compensate this lack of employer-funded training by their own training investments, which explains why their training does not focus on the firm-specific skills they need for their current job but, rather, on the general skills needed for finding another job. This being said, conditional on the fact that they do receive employed-funded training, flexworkers are more likely than permanent workers to receive general than firm-specific training.

\footnotetext{
${ }^{11}$ For self-paid training we do not make the distinction between general and firm-specific because it is by and large general (see Table 3).

${ }^{12}$ Nevertheless, it could be the case that paying for one's own training generates a chain in which the temporary workers get employer-funded training which increases their opportunities for making a transition to a permanent job. However, the existence of such chains cannot be tested with the data at hand.

${ }^{13}$ According to Table 2, about one-third of general training is not work related.

${ }^{14}$ The policy conclusions in this section are the sole responsibility of the first two authors.
} 
Furthermore, we analyse to what extent training participation is related to flexible wokers's labour market mobility. We find that for temporary workers, participation in employer-funded firm-specific training is related to improved opportunities for a transition to a permanent contract with their employer. This is consistent with Autor's (2001) idea that firms use training in the selection process for their permanent staff. However, participation in self-paid training is not related to finding a better job.

The lower training participation of flexworkers is likely to impede workers' adaptability to changing skill demands in the labour market. This suggests that there is indeed a trade-off between labour market flexibility and training participation as argued by Arulampalam and Booth (1998). However, this does not hold for workers with flexible contracts whose participation in employer-funded firm-specific training helps them in making a transition towards a permanent contract with the firm. However, flexworkers who do not participate in any employer-funded training cannot adequately compensate this by investing in their own skills. This suggests that the market fails in the skills provision of flexible workers which is required for giving these workers a more sustainable position in the labour market. From a policy perspective, we therefore conclude that if governments want to encourage labour market flexibility, they should be aware of the fact that flexible employment contracts impede employee's human capital investments. This could hamper workers's possibilities to adapt to new skills needs. Increased labour market flexibility therefore needs to be supplemented by additional public facilities or labour legislation ${ }^{15}$ to stimulate employers to invest in training which enables flexworkers to keep their skills up to date.

\section{References}

Acemoglu, D. \& Pischke, J.-S. (1998). Why do firms train? Theory and evidence. Quarterly Journal of Economics, 113(1), 79-119.

Albert, C., García-Serrano, C. \& Hernanz, V. (2005). Firm-provided training and temporary contracts. Spanish Economic Review, 7(1), 67-88.

Allen, J. \& De Grip, A. (2012). Skill obsolescence, lifelong learning and labor market participation. Applied Economics, 44 (25), 3237-3245, (forthcoming).

Almeida-Santos, F. \& Mumford, K. (2004). Employee training in Britain. IZA Discussion Paper, No 1197.

Arranz, J., García-Serrano, C. \& Toharia, L. (2010). The influence of temporary employment on unemployment exits in a competing risks framework. Journal of Labor Research, 31(1), 67-90.

Arulampalam, W. \& Booth, A. (1998). Training and labour market flexibility: Is there a trade-off? British Journal of Industrial Relations, 36(4), 521-536.

Autor, D. (2001). Why do temporary help firms provide free general skills training? Quarterly Journal of Economics, 116(4), 1409-1448.

\footnotetext{
${ }^{15}$ See Denktank Leren en werken (2009)
} 
Barron, J., Black, D. \& Loewenstein, M. (1989). Job matching and on-the-job training. Journal of Labor Economics, 7(1), 1-19.

Bassanini, A., Booth, A., Brunello, G., De Paola, M. \& Leuven, E. (2007). Workplace training in Europe. In: Brunello, G., Garibaldi, P. \& Wasmer, E. (Eds.). Education and Training in Europe. Oxford: Oxford University Press, pp. 143-309.

Becker, G. (1975). Human capital: a theoretical and empirical analysis, with special reference to education (2nd ed.). New-York: National Bureau of Economic Research.

Bierings, H., Cörvers, F., Montizaan, R. \& de Vries, R. (2009). Bruikbaarheid longitudinale gegevens Enquête Beroepsbevolking. ROA-TR-2009/2. ROA: Maastricht.

Booth, A. L. \& Chatterji, M. (1995). Training and contracts. Dundee Discussion Papers in Economics, No 64.

Booth, A. L., Francesconi, M. \& Frank, J. (2002). Temporary jobs: Stepping-stones or dead ends? Economic Journal, 112(480), F189-F213.

Booth, A. L. \& Snower, D. J. (1996). Acquiring Skills, Market Failures, Their Symptoms and Policy Response. Cambridge: Cambridge University Press.

Cörvers, F., Euwals, R. \& de Grip, A. (2011). Labour Market Flexibility in the Netherlands. The Hague, De Swart

Crawford, V. P. (1988). Long-term relationships governed by short-term contracts. American Economic Review, 78(3), 485-499.

Crawford, V. P. (1990). Relationship-specific investment. Quarterly Journal of Economics, 105(2), 561574.

De Graaf-Zijl, M., van den Berg, G. \& Heyma, A. (2010). Stepping stones for the unemployed: The effect of temporary jobs on the duration until (regular) work. Journal of Population Economics, 24(1), 107-139.

Dekker, R. (2007). Non-Standard Employment and Mobility in the Dutch, German and British Labour Market. Ridderkerk: Ridderprint.

Denktank Leren en Werken (2009). Tijd voor ontwikkeling. Advies van de Denktank Leren en Werken over het stimuleren van een leven lang leren in Nederland. Den Haag: Ministeries van Onderwijs, cultuur en Wetenschap en sociale Zaken en Werkgelegenheid.

Draca, M. \& Green, C. (2004). The incidence and intensity of employer funded training: Australian evidence on the impact of flexible work. Scottish Journal of Political Economy, 51(5), 609-625.

Fouarge, D., Schils, T. \& de Grip, A. (2009). Prikkels voor postinitiële scholing van laagopgeleiden. Den Bosch: ecbo.

Forrier, A. \& Sels, L. (2003). Temporary employment and employability: Training opportunities and efforts of temporary and permanent employees in Belgium. Work, Employment and Society, 17(4), 641-666. 
Glassner, V. \& Galgóczi, B. (2009). Plant-level responses to the economic crisis in Europe. ETUI WP 2009.01

Jonker, N. \& de Grip, A. (1999). Do employees with flexible contracts receive less training? ROA Research Memoranda, ROA-RM-1999/1E.

Katz, E. \& Ziderman, A. (1990). Investment in general training: The role of information and labour mobility. Economic Journal, 100(403), 1147-1158.

Kerkhofs, M., Bierings, H. \& de Vries, R. (2009). Werkloosheidsduren op basis van de Enquête Beroepsbevolking, 2002-2007. CBS.

Lazear, E. P. (2009). Firm-specific human capital: A skill-weights approach. Journal of Political Economy, 117(5), 914-940.

Lee, C.H., \& Bruvold, N.T. (2003). Creating value for employees: investment in employee development. International Journal of Human Resource Management, 14(6), 981-1000.

Loewenstein, M. A. \& Spletzer, J. R. (1997). Delayed formal on-the-job training. Industrial and Labor Relations Review, 51(1), 82-99.

Murphy, P., Latreille, P., Jones, M. \& Blackaby, D. (2008). Is there a public sector training advantage? Evidence from the Workplace Employment Relations Survey. British Journal of Industrial Relations, 46(4), 674-701.

OECD (2004). Employment Outlook 2004. Paris: OECD.

Pischke, J. (2001). Continuous training in Germany. Journal of Population Economics, 14(3), 523-548.

Stevens, M. (1994). An investment model for the supply of training by employers. Economic Journal, 104(424), 556-570. 
Table 1: Participation in training and who paid for the training, 2004-2008 (percentages)

\begin{tabular}{|c|c|c|c|}
\hline & \multirow{2}{*}{$\begin{array}{l}\text { Participation } \\
\text { in training }\end{array}$} & \multicolumn{2}{|c|}{ Paid by: ${ }^{1)}$} \\
\hline & & Employer & Employee \\
\hline & $\%$ & $\%$ & $\%$ \\
\hline Permanent employment & 11.5 & 8.9 & 1.5 \\
\hline Total flexible employment & 9.5 & 4.9 & 3.3 \\
\hline Temporary work agency employment & 9.9 & 5.0 & 3.7 \\
\hline Temporary contract & 9.6 & 4.6 & 3.5 \\
\hline On-call employment & 8.9 & 5.4 & 2.5 \\
\hline Total & 11.3 & 8.6 & 1.7 \\
\hline
\end{tabular}

1) excluding training that is neither financed by the employer nor the employee.

Source: CBS, LFS. 
Table 2: Main reason for participation in training, 2004-2008 (percentages)

\begin{tabular}{lccccc}
\hline & To keep up & Compulsory & Promotion & $\begin{array}{c}\text { Another } \\
\text { job }\end{array}$ & $\begin{array}{c}\text { Not work } \\
\text { related }\end{array}$ \\
& $\%$ & $\%$ & $\%$ & $\%$ & $\%$ \\
\hline Permanent employment & 40.5 & 22.7 & 9.8 & 16.4 & 9.7 \\
Total flexible employment & 24.7 & 21.4 & 7.0 & 33.2 & 11.5 \\
Temporary work agency & & & & & \\
employment & 19.2 & 22.5 & 7.5 & 38.8 & 10.3 \\
Temporary contract & 23.5 & 20.9 & 7.4 & 32.8 & 12.4 \\
On-call employment & 37.7 & 20.3 & 5.2 & 23.0 & 12.2 \\
Total & 39.5 & 22.6 & 9.6 & 17.5 & 9.8 \\
\hline
\end{tabular}

Source: CBS, LFS. 
Table 3: Participation in specific and general training, by employer-funded and self-funded training ${ }^{1)}$ 2004-2008 (percentages)

\begin{tabular}{lcccc}
\hline & \multicolumn{2}{c}{$\begin{array}{c}\text { Employer-funded } \\
\text { Firm- } \\
\text { Specific }\end{array}$} & General & \multicolumn{2}{c}{ Self-funded } \\
& Firm- & Specific & General \\
\hline Permanent employment & 7.1 & 1.7 & 0.5 & 1.0 \\
Total flexible employment & 3.6 & 1.2 & 0.9 & 2.5 \\
$\quad$ Temporary work agency & 3.6 & 1.3 & 0.8 & 2.9 \\
employment & 3.3 & 1.2 & 0.9 & 2.5 \\
$\quad$ Temporary contract & 4.2 & 1.1 & 0.8 & 1.7 \\
$\quad$ On-call employment & 6.9 & 1.7 & 0.5 & 1.1 \\
\hline Total & & & & \\
\hline
\end{tabular}

1) excluding training that is neither financed by the employer nor the employee.

Source: CBS, LFS. 
Table 4: Probability of training participation 2004-2008 (marginal effects) ${ }^{1)}$

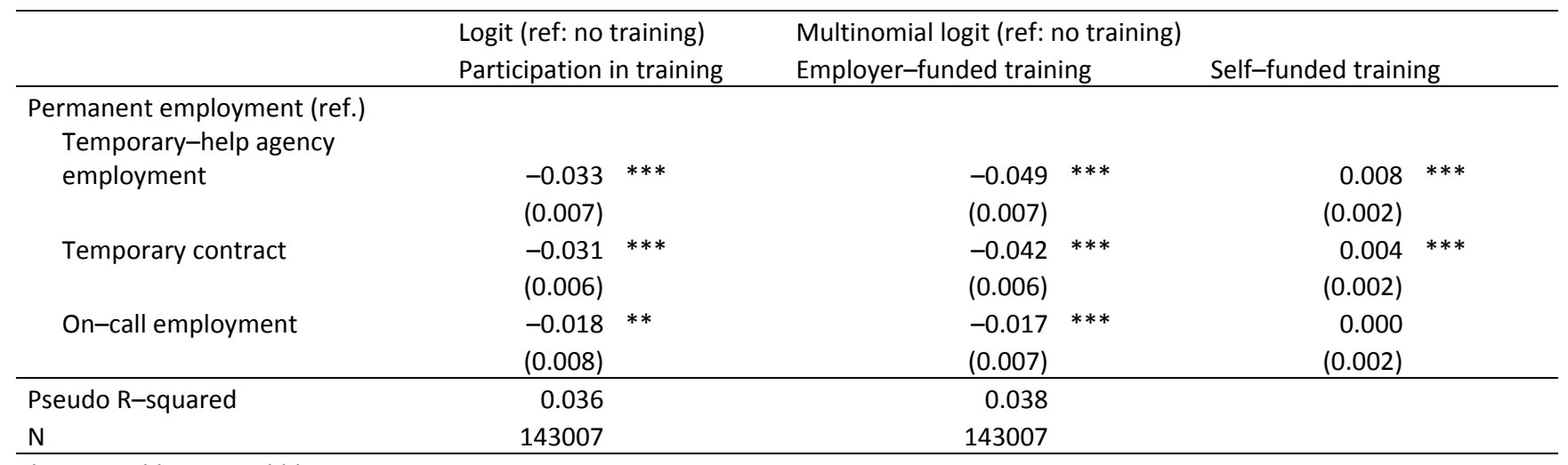

$* \mathrm{p}<0.10, * * \mathrm{p}<0.05, * * * \mathrm{p}<0.01$

Standard errors in brackets

1) Control variables: gender, age and age squared, ethnicity (Western, non-Western migrants), educational level, occupation, part-time work, job tenure (in log), industry sector, region and time dummies.

Source: CBS, LFS. 
Table 5: Participation in training and labour mobility within a year, $2004-2008$ (percentages)

\begin{tabular}{|c|c|c|c|c|c|c|}
\hline & \multicolumn{2}{|c|}{$\begin{array}{l}\text { Losing employment } \\
\text { after one year }\end{array}$} & \multicolumn{2}{|c|}{$\begin{array}{l}\text { Permanent job } \\
\text { after one year }{ }^{2)}\end{array}$} & \multicolumn{2}{|c|}{$\begin{array}{l}\text { Other employer } \\
\text { after one year }^{3)}\end{array}$} \\
\hline & Training & No training & Training & No training & Training & No training \\
\hline & $\%$ & $\%$ & $\%$ & $\%$ & $\%$ & $\%$ \\
\hline Permanent employment & 2.4 & 4.4 & 98.2 & 98.1 & 8.4 & 7.6 \\
\hline Total flexible employment & 15.9 & 17.4 & 57.6 & 48.7 & 30.6 & 32.7 \\
\hline \multicolumn{7}{|l|}{ Temporary work agency } \\
\hline employment & 14.5 & 17.2 & 57.0 & 43.6 & 40.1 & 43.6 \\
\hline Temporary contract & 20.9 & 21.0 & 52.4 & 43.2 & 30.3 & 34.4 \\
\hline On-call employment & 9.3 & 11.2 & 67.1 & 65.8 & 13.2 & 11.5 \\
\hline Total & 3.3 & 5.4 & 96.1 & 95.0 & 9.5 & 9.3 \\
\hline
\end{tabular}

1) Reference: remaining employed.

2) Reference: transition to flexible employment after one year.

3) Reference: remaining with the same employer.

Source: CBS, LFS. 
Table 6: Multinomial logit regression for the probability of flexworkers to experience various types of labour market transition, 2004-2008 (marginal effects) ${ }^{1)}$

$\begin{array}{cccl}\begin{array}{c}\text { Same } \\ \text { employer/ }\end{array} & \text { Other } & \text { Other } & \text { Lose } \\ \text { employer/ } & \text { employer/ } & \text { employment } \\ \text { contract } & \text { flexible work } & \text { permanent } & \\ \text { arrangement } & \text { contract } & \end{array}$

\begin{tabular}{|c|c|c|c|c|c|c|c|c|}
\hline \multicolumn{9}{|l|}{ Temporary work agency employment (ref.) } \\
\hline Temporary contract & $\begin{array}{l}-0.012 \\
(0.013)\end{array}$ & & $\begin{array}{l}-0.044 \\
(0.008)\end{array}$ & $* * *$ & $\begin{array}{l}-0.019 \\
(0.009)\end{array}$ & $* *$ & $\begin{array}{r}0.037 \\
(0.010)\end{array}$ & $* *$ \\
\hline On-call employment & $\begin{array}{r}0.251 \\
(0.014)\end{array}$ & $* * *$ & $\begin{array}{l}-0.139 \\
(0.015)\end{array}$ & $* * *$ & $\begin{array}{l}-0.066 \\
(0.013)\end{array}$ & $* * *$ & $\begin{array}{l}-0.028 \\
(0.013)\end{array}$ & $* * *$ \\
\hline \multicolumn{9}{|l|}{ No training (ref.) } \\
\hline Self-funded training & $\begin{array}{l}-0.013 \\
(0.031)\end{array}$ & & $\begin{array}{r}0.022 \\
(0.018)\end{array}$ & & $\begin{array}{r}0.007 \\
(0.020)\end{array}$ & & $\begin{array}{r}0.057 \\
(0.021)\end{array}$ & $*$ \\
\hline Employer-funded general training & $\begin{array}{r}0.031 \\
(0.038)\end{array}$ & & $\begin{array}{l}-0.013 \\
(0.028)\end{array}$ & & $\begin{array}{r}0.004 \\
(0.027)\end{array}$ & & $\begin{array}{l}-0.033 \\
(0.035)\end{array}$ & \\
\hline Employer-funded firm-specific training & $\begin{array}{r}0.064 \\
(0.023) \\
\end{array}$ & $* * *$ & $\begin{array}{l}-0.036 \\
(0.021) \\
\end{array}$ & * & $\begin{array}{r}0.006 \\
(0.019) \\
\end{array}$ & & $\begin{array}{l}-0.039 \\
(0.023) \\
\end{array}$ & $* * *$ \\
\hline $\mathrm{N}$ & 7683 & & & & & & & \\
\hline Pseudo R-squared & 0.09 & & & & & & & \\
\hline
\end{tabular}

$* \mathrm{p}<0.10 * * \mathrm{p}<0.05 * * * \mathrm{p}<0.01$

Standard errors in brackets

1) Control variables: gender, age and age squared, ethnicity (Western, non-Western migrants), educational level, occupation, part-time work, job tenure (in log), industry sector, region and time dummies.

Source: CBS, LFS. 


\section{Appendix}

Table A.1: Summary statistics

\begin{tabular}{|c|c|c|c|c|c|}
\hline & $\mathrm{N}$ & Mean & & $\mathrm{N}$ & Mean \\
\hline Type of contract & & & Industry sector & & \\
\hline Permanent employment & 134727 & 94.2 & Agriculture & 2242 & 1.6 \\
\hline Temporary work agency employment & 2734 & 1.9 & Industry & 20293 & 14.2 \\
\hline Temporary contract & 3370 & 2,4 & Construction & 9074 & 6.3 \\
\hline On-call employment & 2176 & 1.5 & Sales & 17237 & 12,1 \\
\hline Training & & & Hotel and catering & 2670 & 1.9 \\
\hline No training & 127679 & 89.3 & Transport and communication & 9601 & 6.7 \\
\hline Self-funded training & 2160 & 1.5 & Finance & 20709 & 14.5 \\
\hline Employer-funded training & 13168 & 9.2 & Government & 12782 & 8,9 \\
\hline Reason for training & & & Education & 12322 & 8.6 \\
\hline Training: not work related & 1566 & 1.1 & Personal and social care & 25654 & 17.9 \\
\hline Training: to keep up & 6576 & 4.6 & Culture and other services & 4387 & 3,1 \\
\hline Training: compulsory & 3542 & 2.5 & Other & 6036 & 4.2 \\
\hline Training: promotion & 1208 & 0.8 & Firm size & & \\
\hline Training: another job & 2454 & 1.7 & Less than 10 employees & 18813 & 13,3 \\
\hline Labour market transitions 1 ) & & & 10 to 20 employees & 15968 & 11.2 \\
\hline Same employer/flexible contract & 2330 & 30.3 & 20 to 50 employees & 24824 & 17.4 \\
\hline Same employer/permanent contract & 2326 & 30.3 & 50-100 employees & 19327 & 13.5 \\
\hline Other employer/flexible contract & 872 & 11.3 & >100 employees & 64075 & 44.8 \\
\hline Other employer/permanent contract & 985 & 12.8 & Occupation & & \\
\hline Lose employment & 1170 & 15.2 & General & 8405 & 5.9 \\
\hline Gender & & & Teaching & 9878 & 6.9 \\
\hline Woman & 64871 & 45.4 & Agriculture & 2411 & 1.7 \\
\hline Man & 78136 & 54.6 & Science and engineering & 27108 & 19.0 \\
\hline Etnicity & & & Transport & 6665 & 4.7 \\
\hline Native Dutch background & 126737 & 88.6 & (Para)medical & 12316 & 8.6 \\
\hline Foreign background (Western) & 10926 & 7.6 & Language and culture & 1330 & 0.9 \\
\hline Foreign background (non Western) & 5344 & 3.7 & Behavior en society & 7613 & 5.3 \\
\hline Age & & & Economics & 56049 & 39.2 \\
\hline Age & 143007 & 41.7 & Personal and social care & 8069 & 5.6 \\
\hline Education level & & & Management & 3163 & 2.2 \\
\hline Primary education & 5551 & 3.9 & Region & & \\
\hline Lower secondary education & 25123 & 17.6 & North & 15254 & 10.7 \\
\hline Higher secondary education & 64327 & 45.0 & East & 30718 & 21.5 \\
\hline Higher professional education & 32408 & 22.7 & West & 62216 & 43.5 \\
\hline University education & 15598 & 10.9 & South & 34819 & 24.3 \\
\hline Working hours & & & Survey year & & \\
\hline Part-time worker & 45231 & 31.6 & 2004 & 29777 & 20.8 \\
\hline Full-time worker & 97776 & 68.4 & 2005 & 30774 & 21.5 \\
\hline Tenure & & & 2006 & 27892 & 19.5 \\
\hline \multirow[t]{2}{*}{ Tenure (months) } & 143007 & 131.4 & 2007 & 26666 & 18.6 \\
\hline & & & 2008 & 27898 & 19.5 \\
\hline
\end{tabular}

1) Only for flexworkers.

Source: CBS, LFS. 
Table A.2: Logit model for the probability that employer-funded training is general, 2004-2008 (marginal effects) ${ }^{1)}$ General training

(ref: firm-specific training)

Permanent employment (ref.)

Temporary-help agency employment

Temporary contract

On-call employment

Pseudo R-squared

$\mathrm{N}$

$* \mathrm{p}<0.10, * * \mathrm{p}<0.05, * * * \mathrm{p}<0.01$

Standard errors in brackets

1) Control variables: gender, age and age squared, ethnicity (Western, non-Western migrants), educational level, occupation, part-time work, job tenure (in log), industry sector, region and time dummies.

Source: CBS, LFS.
$0.078 * * *$

(0.027)

$0.065 * *$

(0.026)

0.000

(0.034)

0.031

13116 